\title{
Transformations of Cultural Heritage Objects in Protected Territories
}

JSACE 2/11

Transformations of Cultural Heritage Objects in Protected Territories

Received 2015/02/14

Accepted after revision 2015/05/21

\section{Aušra Mlinkauskienè, Laura Jankauskaitè-Jurevičienè, Salome Katamadze, Anna Kintsurashvili, Kazeem Adayjemi Ajayi, Mesut Topcu}

Kaunas University of Technology, Department of Architecture and Urbanism Studentu str. 48, LT-51367 Kaunas, Lithuania

\section{Marian-Andrei Rata, Nicoleta-Cristina Filca}

Polytechnic University of Timisoara

Piata Victoriei No. 2, 300006 Timisoara, jud. Timis, Romania

*Corresponding author: ausra.mlinkauskiene@ktu.lt

「rossef http://dx.doi.org/10.5755/j01.sace.11.2.12521

Changing socioeconomic, sociocultural, and geopolitical situation influences the physical state and cultural value of built heritage. The diversity of cultural landscapes and regions is also affected by these factors. Continuous maintenance, appropriate use, and professional management are the inseparable parts of modern heritage preservation policies. The protected territories play a crucial role in solving this problem in many countries.

KEYWORDS: immovable cultural heritage, protected territories, heritage transformations.

Changing socioeconomic, sociocultural, and geopolitical situation influences the physical state and cultural value of built heritage. The diversity of cultural landscapes and regions is also affected by these factors. Continuous maintenance, appropriate use, and professional management are the inseparable parts of modern heritage preservation policies. The legal documents and the present state analyzes of the built heritage demonstrate that the existing heritage preservation means cannot arrest the process of built heritage decay. However, the theoretical and practical problems of changes, social use, and preservation of built heritage, as the historical memory, cultural property, resource for tourism, and the integral part of landscape's identity, are not analyzed comprehensively not only in Lithuania, but also in other countries. The protected territories play a crucial role in solving this problem in many countries. The theoretical and practical fundamentals of the institution and formation of the network of protected territories are based on the ideas of natural preservation; however, the legal documents regulating this area indicate that the purpose of the complex protected territories is to preserve, restore, and use the cultural objects and landscape complexes (Mlinkauskiene, 2010).

\section{Introduction}

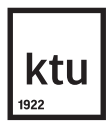

Journal of Sustainable Architecture and Civil Engineering Vol. 2 / No. 11 / 2015

pp. $5-12$

DOI 10.5755/j01.sace.11.2.12521 (c) Kaunas University of Technology 
According to the recommendations of IUCN (the International Union for Conservation of Nature), the national parks should be instituted for the preservation of large natural areas; meanwhile, regional parks should be instituted for the protection of the exceptional areas of culturized landscape. The priorities of regional parks should be the use and maintenance of valuable landscape features and cognitive recreation (Parks, 1994).

The reuse of the built heritage in new circumstances fosters its renovation and conversion. The processes of innovation are hardly compatible with the preservation of authenticity. However, the main aim of the preservation of the built heritage in protected territories is to preserve all the identified valuable properties and to retain regional cultural peculiarities and the main strategic aim of the development of protected areas is to assure the protection of natural and cultural properties, to reach gradually the European standards of protection and to adjust the management of built heritage to the new economic and social conditions (Mets, 2002).

Article describes three cultural heritage objects, investigated in 2013-2014 years period, at different type protected territories. Main criterias to select objects were chosen: objects that were recently registered to the registry of heritage; objects at different type of protected territories, objects at popular and tourists' visited places; objects that were used and part of protected complex ( 1 table).

The purpose of the article - to find purposes of real changes of the cultural heritage objects in protected territories.

Main types of protected territories

Protected territories can be: protected areas, urban territories or sites, complexes (Fig. 1). Protected areas are established in order to preserve territorial complexes and objects of the natural and cultural heritage. By classification of protected areas there are: conservational, preservational, recuperational and integrated protected areas, which have smaller types of protected areas. Conservational priority areas included strict reserves, reserves and objects of heritage monuments. All these types can be for natural and cultural territories or objects. Preservational and recuperational areas mainly established for protection of natural sources. Integrated areas have such types, us national and regional parks and biosphere monitoring areas. All these areas established for scientific research, for preserving territorial complexes and sites of natural or cultural heritage, for cognitive tourism and etc. (Republic of Lithuania Law of Protected..., 2010).

Protected urban territories established for the protection of the historical parts of cities distinguished from the urban point of view, the towns and sites containing architecturally valuable clusters or complexes of buildings and structures. Protected urban areas can have special regimes for different type or territories: historical

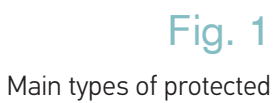
territories

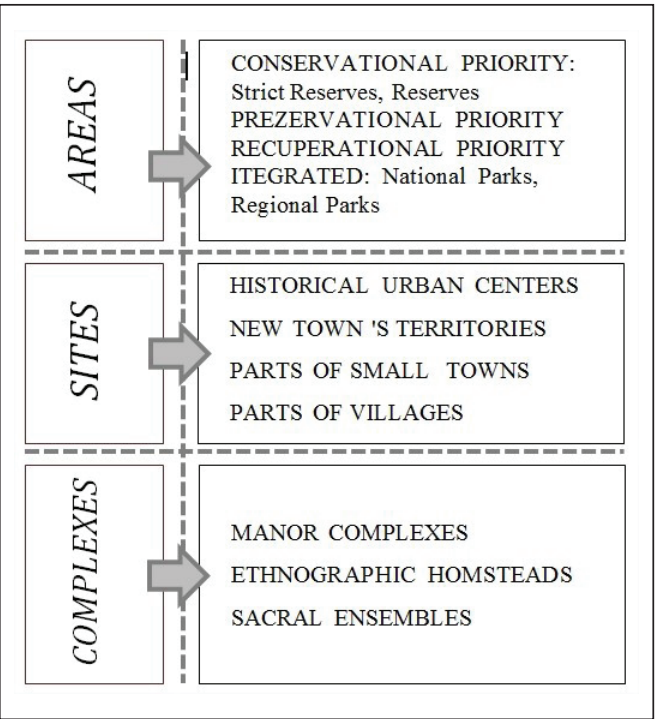
centers or new town areas. The historic urban landscape is embedded with current and past social expressions and developments that are place-based. It is composed of character-defining elements that include land uses and patterns, spatial organization, visual relationships, topography and soils, vegetation, and all elements of the technical infrastructure, including small scale objects and details of construction (Vienna Memorandum, 2005).

Territories of cultural heritage complexes are smaller protected areas with a group of objects which is significant in its totality. Complex object can be manor complex, ethnographic homstead, sacral ensemble and etc. (Republic of Lithuania Law of Protection of Immovable..., 2013). 
The notion of change can be rarely observed in the heritage preservation field as this activity is based on the preservation of valuable features and physical state of heritage objects and the built heritage objects are treated as static valuable entity. In such a situation the notion of built heritage changes can be viewed negatively as it is used for the description of declining valuable features, authenticity or deteriorating physical state. However, the changes of the built heritage because of the influence of the internal and external factors are the complex phenomenon with negative as well as positive results. This determines the need of such notions: negative changes of built heritage and positive built heritage changes. The negative built heritage changes are caused by destructive interventions and negative consequences on built heritage objects; meanwhile, the positive changes are based on the interventions necessary for the preservation of built heritage object (Mlinkauskiene, 2010).

The factors influencing cultural heritage changes can be subdivided into internal and external (Fig. 2). The external factors can be characterized by the indirect effects on built heritage objects and influence all the categories of built heritage. External influence can be mainly characterized by the material or physical changes of the object. The internal factors can be characterized not only by material or physical features of change, but also by the

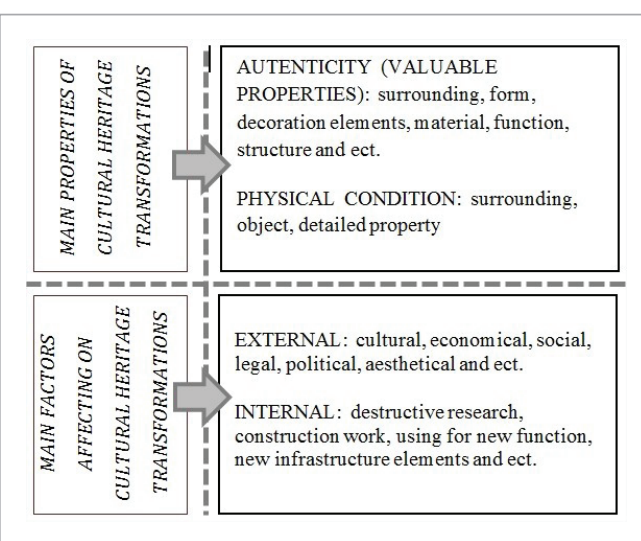
changes of the spiritual meaning or perceptions of the object. The changes of spiritual meaning or perceptions affect such characteristics as: historic memory, philotopic value, traditions, ethnic issues, and links with surrounding cultural and natural environment (Minkevičius, 2005).

The research is focused not only on nowadays condition of the building but also shows how different conditions were changed during the exploitation. The analysis of built heritage is based on the following stages:

Historical details about the cultural heritage objects. It aims at analyzing the significant historical data and documents related with the built heritage objects; to evaluate the existing data of previous analyses concerning the physical state and cultural value of these objects; to determine the location of the objects.

Site analysis is the main stage of the identification of built heritage changes. On site analysis aims at evaluation of the complexity of the object, to determine its geographical localization, to assess its physical state and valuable properties, to record the object in photographs.

Architectural drawings and photos of the buildings with current state. This part consist analysis of curren state in visual aspect. This is one of the main part of the investigation of objects of cultural heritage. These studies have long-lasting value.

Evaluation of physical condition of cultural heritage objects. It is defined as the testing of the objects by analyzing the deviations from the normal state related with physical state, the threat of the environmental impacts and providing preliminary preservation recommendations.

Evaluation of changes of the values of cultural heritage objects. This part means identification of changes of valuable properties (qualitative changes) of heritage objects. The quality standard was determined for the qualitative analysis and the standard features were evaluated by points.

Definition of cultural heritage transformations

Fig. 2

Main factors of Cultural Heritage Changes
The methodological principles for the evaluation of cultural heritage objects 
The results of cultural heritage analysis
Table 1

Data of cultural heritage objects' investigation for period of 2013-2014 years at different type protected territories.
Analysis of cultural heritage transformations was carried out in different territorial areas and different architectural objects ( 1 table). One of evaluated object was in Panemuniai regional park (Report (3), 2014), second one was an object at protected urban territory (Report (1), 2014) and the last object - as part of heritage complex objects (Report (2), 2013).

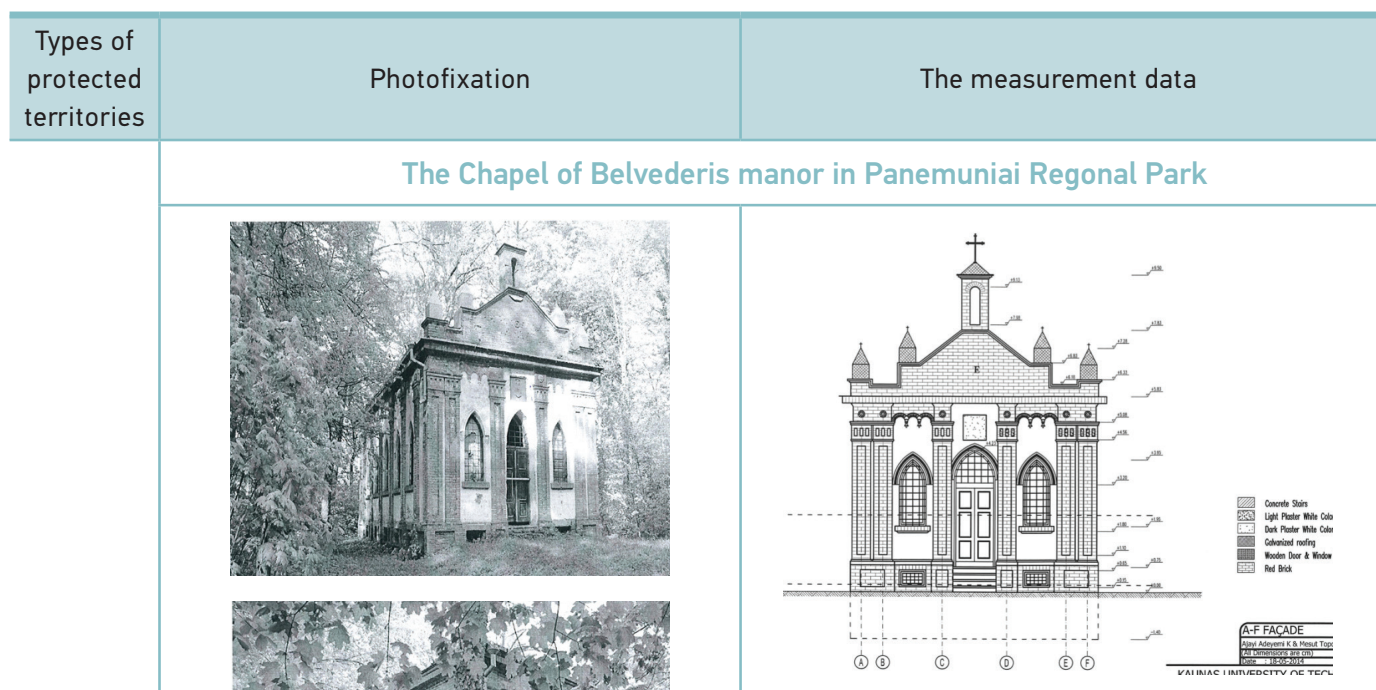

Facade made by students:

Mesut Topcu, Ajayi Aeyemi Kazeem, 2014 y.

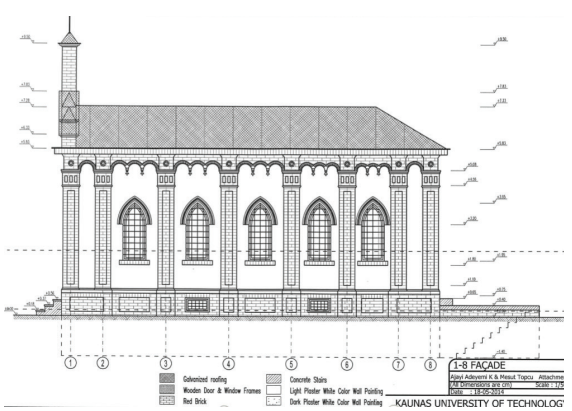

Facade made by students:

Mesut Topcu, Ajayi Aeyemi Kazeem, 2014 y.

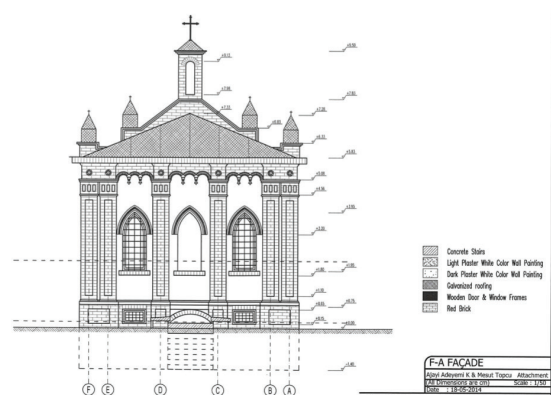

Facade made by students:

Mesut Topcu, Ajayi Aeyemi Kazeem, 2014 y.

Photo taken by Milda Bugailiškytè, 2012-07-18 References: http://kvr.kpd.lt/heritage/ Pages/KVRDetail.aspx?lang=lt\&MC=967
Measurements drawings made by Students: : Mesut Topcu, Ajayi Aeyemi Kazeem, 2014 y. 
Guard house a part of "Board of armaments research laboratory building complex" in Kaunas Žaliakalnis district
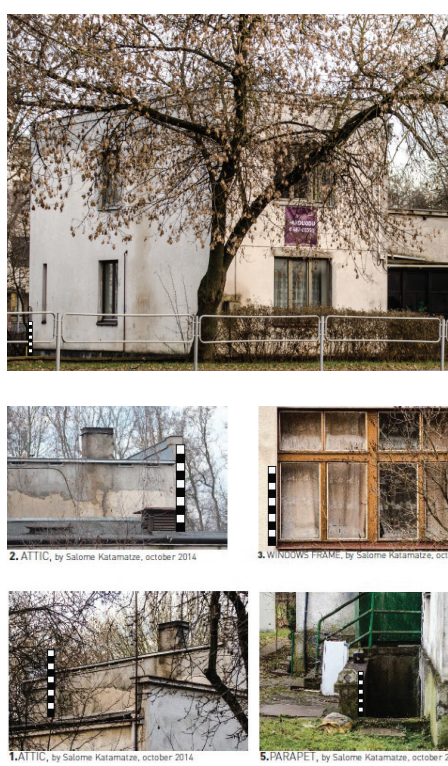

Photos taken by students: Salome Katamedze, Anna Kintsurashvili, Andrei Rata, Cristina Filca, 2014 y.
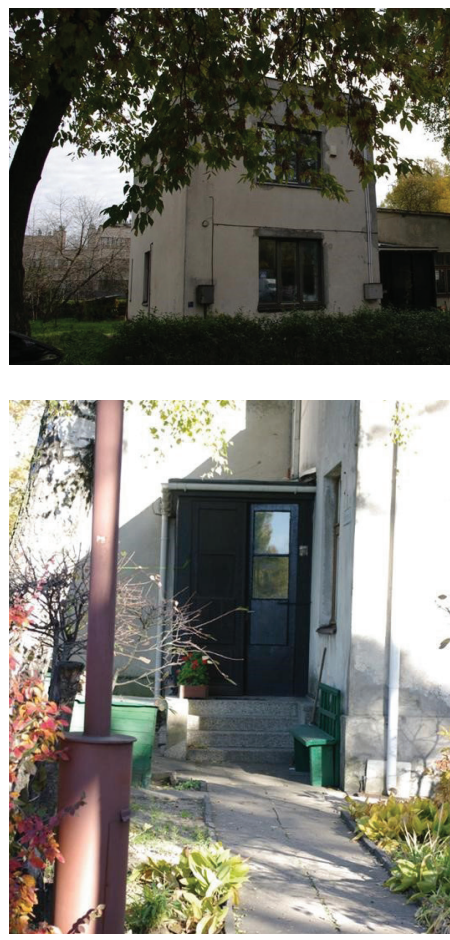

Photos taken from reference (2010 y.) : http://kvr.kpd.lt/heritage/Pages/KVRDetail. aspx?lang $=$ tt $\& M C=28567$

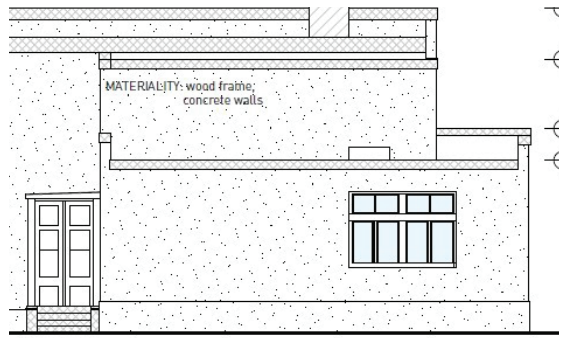

Facade made by students:

Salome Katamedze, Anna Kintsurashvili, Andrei Rata, Cristina Filca, 2014 y.

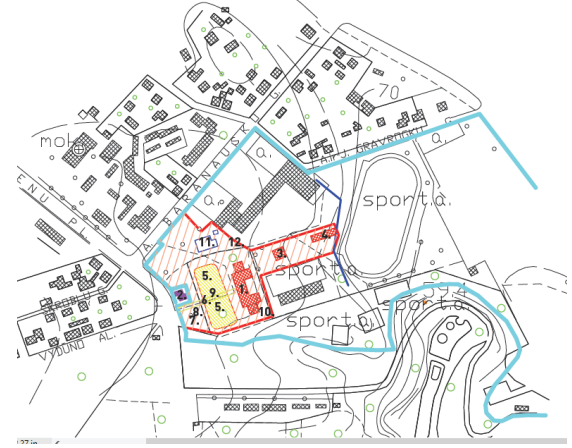

Site plan, made by students:

Salome Katamedze, Anna Kintsurashvili, Andrei Rata, Cristina Filca, 2014 y.

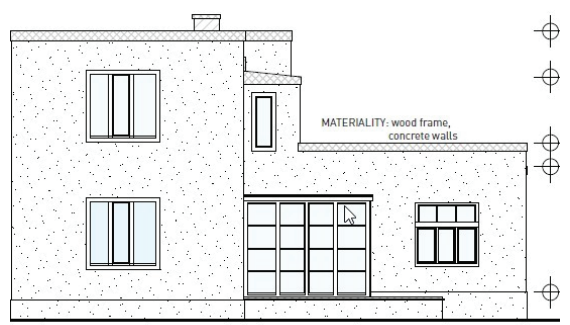

Facade made by students:

Salome Katamedze, Anna Kintsurashvili, Andrei Rata, Cristina Filca, 2014 y.

Measurements drawings made by Students: Salome Katamedze, Anna Kintsurashvili, Andrei Rata, Cristina Filca, 2014 y. 


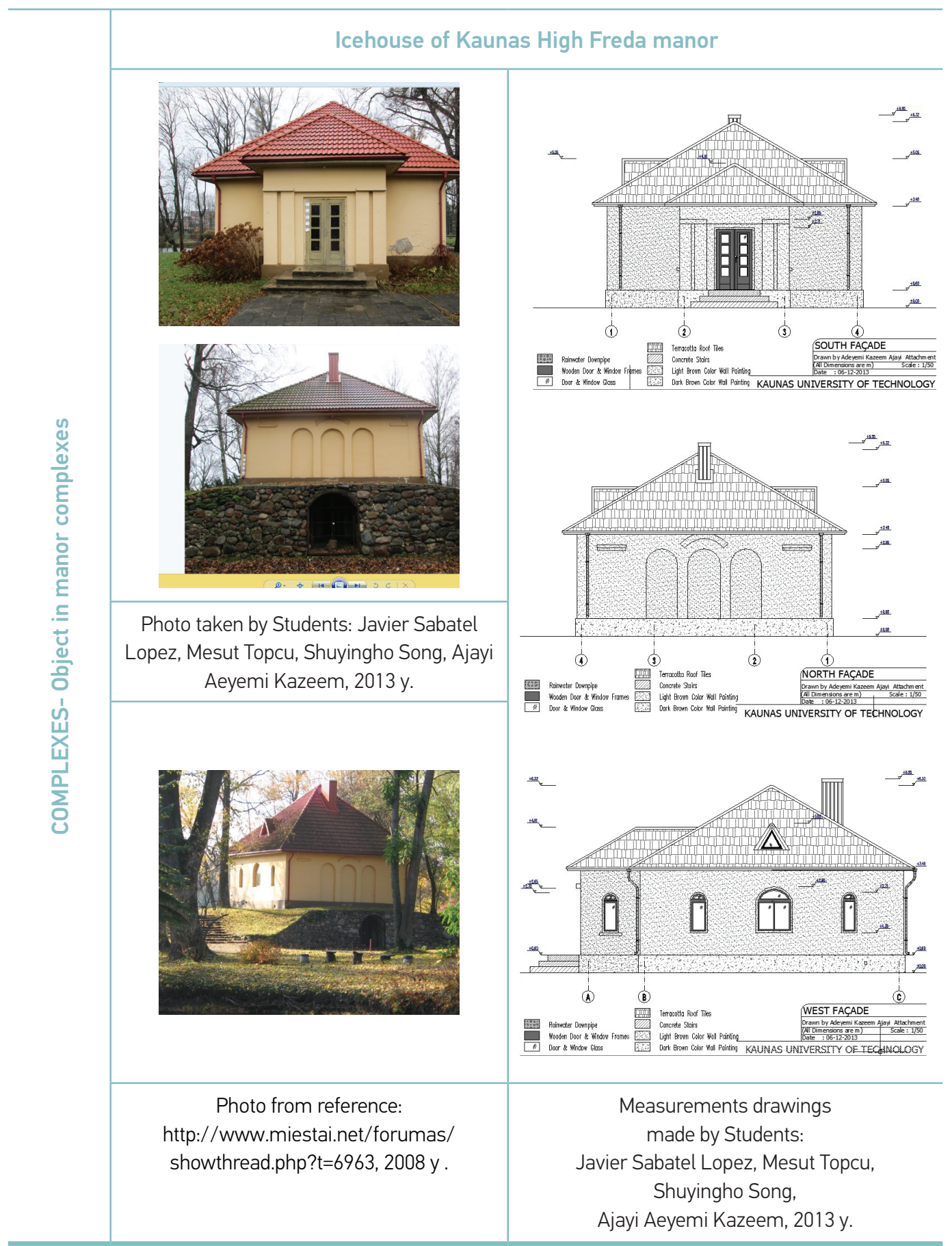

\section{Evaluation of physical condition and valuable properties of cultural heritage objects}

Evaluation of physical condition of cultural heritage objects is one of most important part. The physical state of the abandoned objects is rapidly decaying. It consists of evaluation and comments about physical state changes and main influences of this process. The main factors that affect the physical heritage of the object changes are: external factors - climate impact (humidity and etc.), lack of funding and social impact; and internal factors - function and use of heritage objects, construction work. 
It was determined that the external and internal factors cause positive and negative, long-term and short-term influence on built heritage objects. It was also determined that the changes of valuable features of built heritage object significantly influence its use: the most significant alterations were identified in abandoned declining objects. When built heritage objects are adapted to the new functions their valuable features change only partially and the balance between authentic features and innovations is sustained. The primary uses guaranty the best retention of the valuable features.

The links between the authentic features and the physical state of the cultural heritage objects were also observed: the improvement of physical state conditions declined from the authentic features and cultural value. The decay of physical state does not condition such rapid decline of authenticity.

1 The complex protected territories (regional parks and ect.) are formed on the basis of environmentalist interests. Meanwhile the built heritage objects existing in these territories should be evaluated according to the provisions of contemporary international heritage preservation and, as the product of history, should be used for the purposes of scientific research, public cognitive recreation, use, and respect.

2 The analysis of cultural heritage objects' changes demonstrated that built heritage objects are affected by their environment and are constantly changing. The transformations of heritage objects are caused by internal or external factors, which can have positive and negative, direct and indirect, qualitative and quantitative, short-term and long-term influence. The changes of the cultural heritage objects existing in the protected territories are related not only with the transformations of their physical state, but also with the alterations of their valuable features: authenticity, significance, and aesthetic attractiveness.

3 Investigations of cultural heritage objects performed in 2013-2014 showed that objects' 3 physical and cultural value slightly changed, comparing data with Cultural heritage registry data base (2008-2012) and present objects' state. Physical changes were most influenced by natural factors. Value properties of objects for the compared period remained unchanged. Its possible to state that optimal evaluation period of heritage objects is 5 years.

Mets T., Skar B. 2002. Cultural Heritage Monitoring in Europe. Oslo, the Norvegiant institute for Cultural Heritage Research.

Minkevičius J. 2005. Lietuvos kraštovaizdis kaip tautos dvasios formantas. Konferencija: Lietuvos kraštovaizdžio vizija. Straipsnių rinkinys. Kaunas, Technologija.

Mlinkauskiene A. 2010. The changes of the state of immovable cultural heritage in Lithuanian regional parks and the methodology of their valuation: summary of doctoral dissertation: technological sciences, environmental engineering (04T); Kaunas University of Technology, Lithuanian Energy Institute: Technologija.

Parks for Life. 1994. Action of protected areas in Europe, IUCN.
Report (1) for Cultural Heritage subject. 2014. Research of Cultural Heritage object - Guard House in Kaunas Žaliakalnis District. Students: Salome Katamadze, Anna Kintsurashvili, Andrei Rata, Cristina Filca. Teachers: Aušra Mlinkauskienè, Laura Jankauskaitè-Jurevičienè. Kaunas, Kaunas University of Technology.

Report (2) for Cultural Heritage subject. 2013. Research of Cultural Heritahe object Icehouse of Kaunas High Freda manor. Students: Javier Sabatel Lopez, Mesut Topcu, Shuyngbo Song, Ajayi Adeyemi Kazeem. Teachers: Aušra Mlinkauskienè, Laura Jankauskaitè-Jurevičienè. Kaunas, Kaunas University of Technology.

Report (3) for Practise of Cultural Research. 2014. Report of Belvederis Manor Chapel. Students: Adeyemi Kazeem Ajayi, Mesut Topcu. Teacher:

\section{Conclusions}

\section{References}


Aušra Mlinkauskienè. Kaunas, Kaunas University of Technology.

Republic of Lithuania Law of Protected Areas, 2001 (9 November 1993 No I-301, (As last amended on 4 December 2001 - No IX-628)), Vilnius.

Republic of Lithuania Law of Protection of Immovable Cultural Heritage, 2013, (22 December 1994 No I-733,
(As last amended on 10 October 2013 - No XII-549)), Vilnius.

Republic of Lithuania. Register of Immovable Cultural Heritage. Looking by internet: http://kvr.kpd.lt/ heritage/ , 20150610.

Vienna Memorandum, Durban, 2005. Looking by internet: http://whc.unesco.org/archive/2005/ whc05-15ga-inf7e.pdf, 20150601.

\section{About the authors}

\section{AUŠRA MLINKAUSKIENE் Assoc. Professor \\ Kaunas University of Technology, Faculty of Civil Engineering and Architecture, Departament of Architecture and Urbanism \\ Main research area \\ Protection of immovable cultural heritage objects; research of values of cultural landscapes and urban structures; evaluation of protected areas}

\section{Address}

Studentu 48, LT-51367

Kaunas, Lithuania

Tel. +37068479181

E-mail:

ausra.mlinkauskiene@

ktu.lt

\section{KAZEEM \\ ADAYJEMI AJAYI}

Bachelor student

Kaunas University of Technology, Faculty of Civil Engineering and Architecture, Departament of Architecture and Urbanism

\section{Main research area}

Architecture

\section{Address}

Studentu 48, LT-51367

Kaunas, Lithuania

E-mail:

yemzee05@yahoo.com

\section{LAURA \\ JANKAUSKAITÉ- JUREVIČIENĖ}

\section{Lecturer}

Kaunas University of Technology, Faculty of Civil Engineering and Architecture, Departament of Architecture and Urbanism

\section{Main research area}

Research of immovable cultural heritage objects; research of road transport and water engineering and tourism recreational systems

\section{Address}

Studentu 48, LT-51367

Kaunas, Lithuania

Tel. +370 68874418

E-mail:

laura.jankauskaitejureviciene@ktu.lt

\section{MESUT}

TOPCU

\section{Bachelor student}

Kaunas University of Technology, Faculty of Civil Engineering and

Architecture, Departament of Architecture and Urbanism

\section{Main research area}

Architecture

\section{Address}

Studentu 48, LT-51367

Kaunas, Lithuania

E-mail:

mesuttopcu@msn.com

\section{SALOME KATAMADZE \\ Bachelor student \\ Kaunas University of \\ Technology, Faculty of Civil Engineering and Architecture, Departament of Architecture and Urbanism}

Main research area

Architecture

\section{Address}

Studentu 48, LT-51367

Kaunas, Lithuania

E-mail:

saliqatamadze@yahoo. com

\section{MARIAN-ANDREI \\ RATA}

Bachelor student

Polytechnic University of Timisoara

\section{Address}

Piata Victoriei No. 2, 300006 Timisoara, jud. Timis, Romania E-mail: rata.marian.andrei@ gmail.com

\section{ANNA KINTSURASHVILI Master student \\ Kaunas University of Technology, Faculty of Civil Engineering and Architecture, Departament of Architecture and Urbanism}

\section{Main research area} Architecture

\section{Address}

Studentu 48, LT-51367

Kaunas, Lithuania

E-mail: anokintsurashvili@ gmail.com

\section{NICOLETA- CRISTINA FILCA}

\section{Master student}

Polytechnic University of Timisoara

\section{Main research area}

Architecture

\section{Address}

Piata Victoriei No. 2, 300006 Timisoara, jud. Timis, Romania E-mail: filca.cristina@ yahoo.com 